\title{
SENSOR BERGERAK UNTUK PENGENALAN SUMBER CAHAYA DALAM RANGKA PENGHEMATAN ENERGI LISTRIK
}

\author{
Djunaidi Santoso; Leonard Goeirmanto \\ Computer Science Department, School of Computer Science Binus University \\ Jl. K.H. Syahdan No. 9, Palmerah, Jakarta Barat 11480 \\ djunsan2002@yahoo.com
}

\begin{abstract}
Insufficient electricity supply in Java, Indonesia, has become an critical problem to be dealt by the goverment. One solution campaigned by the government is using electricity effectively by turning off unused devices that waste electricity. To make this action as a routine needs a reminder that can help remind people continually. One example of a reminder is an automatic static sensor which is already applied in some places. Dynamic sensor is one of best method to save energy because it can warn the user to turn off unused lamps. Dynamic sensor is also called moving sensor because it is able to move from a place to another and has a wide service area. This study gives information about the use of moving sensor in some areas in order to save electricity energy. As a pilot project, the use of moving sensor needs to be improved by a further study.
\end{abstract}

Keywords: saving electricy energy, reminder, moving sensor

\begin{abstract}
ABSTRAK
Kurangnya pasokan listrik di Jawa, Indonesia, telah menjadi masalah kritis yang harus ditangani oleh pemerintah. Satu solusi yang kerap dikampanyekan oleh pemerintah adalah menggunakan listrik secara efektif dengan mematikan perangkat listrik yang tidak terpakai. Untuk membuat kegiatan penghematan listrik ini menjadi rutinitas dibutuhkan pengingat yang dapat membantu mengingatkan masyarakat secara terus-menerus. Salah satu contoh pengingat adalah sensor otomatis statis yang sudah diterapkan di beberapa tempat. Sensor dinamis adalah salah satu metode terbaik untuk menghemat energi karena dapat mengingatkan penggunanya untuk mematikan lampu yang tidak terpakai. Sensor dinamis juga disebut sensor bergerak karena mampu berpindah dari satu tempat ke lain dan memiliki wilayah jangkauan luas. Studi ini memberikan informasi tentang penggunaan sensor bergerak di beberapa daerah dalam rangka penghematan energi listrik. Sebagai proyek awal, penggunaan sensor bergerak perlu ditingkatkan dengan studi lebih lanjut.
\end{abstract}

Kata kunci: penghematan energi listrik, pengingat, sensor bergerak 


\section{PENDAHULUAN}

Krisis energi listrik yang berkelanjutan menjadi masalah penting di Indonesia. Pemadaman bergilir di wilayah pulau Jawa telah menimbulkan kerugian ekonomi dan sosial bagi masyarakat. Upaya peningkatan sumber daya listrik bertenaga nuklir yang merupakan salah satu solusi dalam menghadapi peningkatan konsumsi energi listrik masih terus mendapat tantangan akan kelayakan tempat dan lingkungan. Alternatif energi listrik menggunakan angin, sinar matahari dan panas bumi masih belum dapat memenuhi kebutuhan yang ada. Pengembangan kapasitas sumber energi listrik yang terbatas dan umur peralatan yang perlu regenerasi mengakibatkan berbagai masalah dalam pasokan energi listrik.

Selain rencana penambahan kapasitas energi listrik, pemerintah juga sering menghimbau masyarakat untuk melakukan penghematan penggunaan listrik. Kedua cara ini dijalankan pemerintah dalam upaya mengatasi krisis energi. Dalam upaya penambahan pembangkit listrik, pemerintah menghadapi tantangan dari dunia internasional untuk mencari alternatif selain sumber batu bara. Alasannya adalah pembangkit listrik tenaga batu bara mengakibatkan lebih dari sepertiga pemanasan global di seluruh dunia (Ferrey, 2010, p.73). Upaya untuk penghematan energi listrik, pemerintah juga menghadapi tantangan kesadaran dan perilaku masyarakat. Pemborosan penggunaan energi listrik masih kurang disadari oleh masyarakat. Slogan untuk penghematan energi listrik sudah digunakan oleh pemerintah sebagai salah satu cara untuk mengatasi masalah krisis energi listrik. Slogan yang dimasyarakatkan melalui iklan radio, iklan televisi dan berbagai baliho di jalan raya mengajak masyarakat untuk peduli akan krisis energi yang sedang terjadi.

Sebagian besar negara berkembang mengembangkan kapasitas sumber listriknya dengan membangun pembangkit tenaga listrik dengan tenaga batu bara (Ferrey, 2010, p.71). Mayoritas sumber daya listrik yang dimiliki Indonesia juga masih menggunakan energi fosil yang memiliki dampak buruk bagi lingkungan hidup. Efek pemanasan global sebagai salah satu dampak penggunaan energi fosil juga telah menjadi sorotan dunia internasional. Penghematan energi secara internasional juga mulai digalakkan, salah satunya adalah program jam untuk bumi atau dikenal earth hour. Program yang dimulai tahun 2007 di Sydney ini setiap tahun telah berhasil melakukan penghematan energi listrik di seluruh dunia (Ahmed, 2010, p.1).

Industri atau gedung-gedung tinggi merupakan konsumen energi listrik cukup besar sehingga memadamkan lampu jika tidak digunakan pada area ini pasti akan menghemat energi listrik (Bagci, 2009, p.157). Penggunaan sensor ini sebagian besar masih bersifat statik (Wang dan Xiao, 2006, p.727). Sensor statik hanya mampu melayani daerah tertentu sesuai jangkauan sensor. Sensor statik untuk lampu sudah banyak dijual dan digunakan memanfaatkan cahaya matahari sebagai acuan. Pada tempat-tempat yang tak terjangkau cahaya matahari, sensor ini tak bisa digunakan. Biasanya bangunan industri atau ruangan di gedung-gedung tinggi tidak disinari matahari. Sensor bergerak yang dirancang pada penelitian ini berfungsi untuk memberikan peringatan jika ada lampu yang masih menyala. Sensor ini dirancang untuk digunakan pada bangunan industri maupun ruangan di gedung-gedung tinggi dengan posisi letak tertentu. Dengan semakin bertambahnya daerah layanan sensor, maka akan semakin besar juga penghematan listrik yang bisa dilakukan. Penghematan listrik ini akan membantu upaya pemerintah dalam mengatasi krisis energi listrik.

\section{METODE}

Penelitian dilakukan dengan merancang peta lintasan pada gedung dan bangunan industri. Setiap lintasan dalam industri bersifat unik sehingga setiap lintasan hanya berlaku untuk satu tempat 
saja. Rancangan lintasan ini akan mempengaruhi konsumsi energi dari sensor bergerak yang mempengaruhi jangka waktu kerjanya. Perangkat sensor biasanya menggunakan tenaga baterai yang tanpa pembaharuan (Wang, 2006, p.723).

Rancangan lintasan ini menjadi input dalam sistem kontrol. Bagian kontrol menyimpan data kontrol parameter (Padmanabh dan Vuppala, 2009). Parameter lintasan ini memberikan informasi awal, arah dan akhir pergerakan sensor bergerak. Sistem kontrol ini akan mengolah data parameter dan memberikan instruksi untuk pergerakan mekanik. Pergerakan mekanik menggunakan motor servo dengan sumber daya dari baterai.

Pergerakan menggunakan sumber daya baterai memiliki keterbatasan dalam umur baterai. Saat akan digunakan, peralatan sensor ini perlu diperiksa terlebih dulu keadaan baterai agar dapat melakukan perjalanan secara penuh. Kecepatan motor servo biasanya tetap dan cenderung melambat jika keadaan baterai berkurang.

Setelah pergerakan mekanik diatur di sistem kontrol lintasan, selanjutnya dibuat data parameter untuk sensor cahaya. Data untuk sensor cahaya ini ada dua macam, yaitu: bagian yang perlu dan yang tak perlu dideteksi. Bagian yang tidak perlu dideteksi merupakan tempat yang memang harus ada cahaya, sehingga lampu boleh dibiarkan menyala. Sedangkan bagian lainnya harus dideteksi oleh sensor cahaya. Deteksi cahaya akan memberikan peringatan sehingga pengguna akan mengetahui akan adanya lampu yang masih menyala. Penelitian ini dibatasi sampai memberikan peringatan saja.

Sistem sensor cahaya akan kembali diuji coba pada lintasan gedung dan bangunan industri yang digunakan pada tahap perancangan dan uji coba. Saat uji coba ini perlu dilakukan juga penggantian data parameter lintasan dan perbaikan jika ditemukan kesalahan. Tentunya pemeriksaan baterai saat awal uji coba harus tetap dilakukan agar kecepatan pergerakan sensor tetap sama.

\section{HASIL DAN PEMBAHASAN}

Semua rancangan dibuat dalam rangkaian elektronik dan pada awalnya diuji coba keseimbangan peralatan. Dari hasil uji coba awal, peralatan berhasil memiliki keseimbangan sehingga untuk keadaan statik saja peralatan tetap stabil. Setelah uji coba keadaan statik behasil, dilakukan uji coba pergerakan peralatan untuk lintasan lurus saja. Dalam uji coba ini, peralatan sensor berhasil bergerak dan tetap stabil sehingga uji coba dilanjutkan untuk penggunaan sensor-sensor yang ada (Gambar 1 dan 2).

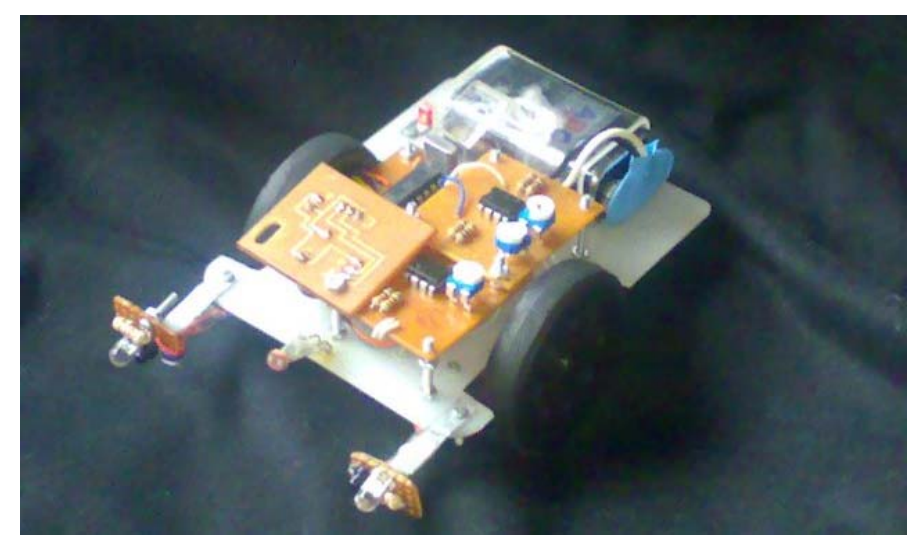

Gambar 1. Tampak peralatan sensor bergerak dari depan. 


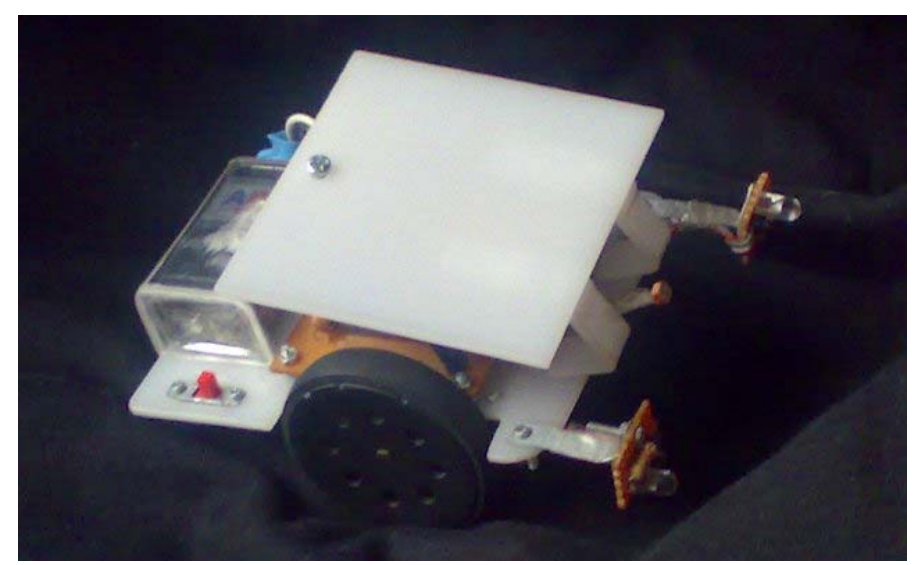

Gambar 2. Tampak peralatan sensor bergerak dari samping.

Uji coba sensor pergerakan dilakukan dan disesuaikan dengan data untuk motor servo yang mengatur pergerakan kedua roda besar. Saat sensor pergerakan menerima data ada halangan pada lintasan, pergerakan salah satu roda dihentikan agar peralatan dapat berputar menghindari halangan tersebut. Uji coba untuk sensor pergerakan ini berhasil untuk berbagai halangan yang disiapkan.

Setelah sensor pergerakan berfungsi, uji coba sensor cahaya dan bunyi peringatan dilakukan. Uji coba awal ini menggunakan lampu senter yang disorotkan langsung pada sensor cahaya. Selama pergerakan tanpa kena sorotan lampu senter, peralatan bergerak terus. Saat disorot lampu senter, peralatan berhenti dan memberikan bunyi peringatan, lalu setelah tidak disorot lagi, peralatan kembali bergerak. Setelah uji coba menggunakan lampu senter berhasil, dilakukan juga uji coba menggunakan cahaya yang ada pada ruangan dan sensor dapat menerima cahaya dalam ruangan sehingga peralatan juga berhenti dan peringatan melalui bunyi diberikan.

Lintasan yang harus dilalui perlatan diperoleh setelah melakukan survey pada tempat uji coba. Lintasan dibuat untuk satu lantai sebuah gedung kantor di Jakarta dan dua buah gudang di kawasan industri di Bogor dan Tangerang. Lintasan diterjemahkan dalam koordinat sumbu X dan Y serta panjang pergerakan dari satu titik ke titik lainnya. Setelah data lintasan dibuat, data tersebut disimpan dalam IC dan selanjutnya dilakukan uji coba di lapangan. Setiap selesai uji coba, dilakukan perbaikan data lintasan dan kedaan yang dilalui peralatan sensor.

Tabel 1

Hasil Uji Coba Lintasan

\begin{tabular}{llll}
\hline Uji Coba & Wilayah & Berhasil & Masalah \\
\hline Pertama & Jakarta & sebagian & $\begin{array}{l}\text { pada lintasan ada halangan cahaya dari benda- } \\
\text { benda dan bayangannya }\end{array}$ \\
\cline { 2 - 4 } & Bogor & sebagian & $\begin{array}{l}\text { terdapat beberapa lintasan yang tertutup } \\
\text { bayangan }\end{array}$ \\
\cline { 2 - 4 } & Tangerang & sebagian & $\begin{array}{l}\text { terdapat beberapa lintasan yang tertutup } \\
\text { bayangan }\end{array}$ \\
\hline Kedua & Jakarta & OK & \\
\cline { 2 - 4 } & Bogor & OK & \\
\cline { 2 - 4 } & Tangerang & OK & \\
\hline
\end{tabular}

Pada awal uji coba di tempat yang dilalui masalah yang terjadi mirip yaitu tertutupnya sinar lampu oleh bayangan benda yang lebih tinggi. Lintasan peralatan di lantai membuat halangan yang terjadi di tempat yang lebih tinggi menjadi hambatan pada beberapa titik yang perlu diperiksa. 
Perbaikan halangan ini memberikan hasil yang baik pada kinerja sensor. Lintasan yang dilalui juga diperbaiki karena pada uji coba pertama ada beberapa titik yang tidak dilalui karena berbeda dari hasil survey awal.

Setelah dilakukan perbaikan daerah lintasan dan koordinat lintasan, uji coba yang kedua memberikan hasil yang baik. Bunyi peringatan untuk beberapa kasus yang disiapkan bisa berhasil dan peringatan tersebut dapat didengar.

\section{PENUTUP}

Dari hasil uji coba peralatan ini, diambil kesimpulan: (1) daerah yang akan diperiksa perlu disiapkan untuk bebas dari halangan bayangan yang menjadi hambatan untuk sensor cahaya; (2) data lintasan perlu aktualisasi sesuai keadaan di lapangan; (3) untuk lintasan yang bebas halangan, peralatan sensor bergerak dapat bekerja dengan baik; (4) waktu penelitian yang dikurangi membuat penelitian hanya dilakukan pada lintasan-lintasan pendek dan data lintasan tidak dibuat secara penuh.

Adapun saran untuk penelitian selanjutnya: (1) perlu penambahan sensor untuk pergerakan sehingga sensitivitas peralatan semakin baik; (2) perlu perbaikan sumber energi sehingga lintasan yang dilalui dapat lebih panjang dan lama; (3) perlu uji coba pada banyak lintasan yang memiliki hambatan yang bervariasi.

\section{DAFTAR PUSTAKA}

Ahmed, S. (2010, Mar 28). Lights Out. Tribune Business News.

Bagci, B. (2009). Energy Saving Potential for a High Rise Office Building. Intelligent Buildings International, 1 (2), 156-164.

Ferrey, S. (2010). The Failure Of International Global Warming Regulation to Promote Needed Renewable Energy. Boston College Environmental Affairs Law Review, 37 (1), 67-127.

Padmanabh, K., Vuppala, S. K. (2009). An Adaptive Data Aggregation Algorithm in Wireless Sensor Network with Bursty Source. Wireless Sensor Network, 1 (3), 222-233.

Wang, L. \& Xiao, Y. (2006). A Survey of Energy-Efficient Scheduling Mechanisms in Sensor Networks. Mobile Networks and Applications, 11, 723-742. 